\title{
Quantitative studies on the salivary flora
}

\author{
P. W. ROSS
}

From the Bacteriology Department, University of Edinburgh

SYNOPSIS In a quantitative bacteriological study of the salivary flora from 50 children the following aerobic organisms were identified and enumerated: alpha-haemolytic streptococci, beta-haemolytic streptococci, Streptococcus faecalis, pneumococci, Staphylococcus aureus, Staph. albus and Staph. citreus, Neisseria spp, $N$. meningitidis, corynebacteria, aerobic lactobacilli, $B$. subtilis, $H$. influenzae, coliform organisms, and Candida spp. Many of the known potentially pathogenic members were present in large numbers.

It is suggested that knowledge of the relative numbers of the organisms that comprise the salivary flora will lead to a greater understanding of the ecology of the mouth and of the pathogenesis of oral infections.

The oral flora of man comprises one of the densest and most varied microbial populations in the body, but its composition and proportions have been described by few investigators. Richardson and Jones (1958) reported a total mean aerobic population of $\left(4 \times 10^{7}\right)$ bacteria per millilitre of saliva, with a range of $5 \times 10^{6}-1.1 \times 10^{8}$, and an anaerobic population of $1.1 \times 10^{8}$ bacteria per $\mathrm{ml}$, with a range of $1.0 \times 10^{7}-3.8 \times 10^{8}$, and Hoffman (1966) described counts of $4.3 \times 10^{7}-5.5 \times 10^{9}$ per $\mathrm{ml}$. In addition to the information provided by these investigators on actual numbers of bacteria, important contributions to knowledge of the salivary flora were made by Morris (1953a and b; 1954 a, b, c, and d), Kraus and Gaston (1956), and Kraus (1958).

Many problems attend the study of oral organisms. Not the least of these are the exacting cultural requirements of the spirochaetes and filamentous forms, and the fact that the bacterial population varies according to the area of the mouth sampled; the dental plaque and gingival crevice contain a flora that is unlike that of the saliva. Burnett and Scherp (1962) stated that another variable was the time when the saliva was sampled, since proportions change from day to day and from hour to hour. On the other hand, Johnston and Bodey (1970) recently described a gargling method for obtaining oropharyngeal organisms for culture and these workers stated that the concentration of microorganisms does not alter much during the day.

Despite the fact that many variables and conReceived for publication 15 April 1971. sequently many possibilities of error exist in the study of salivary microorganisms, there are nevertheless certain broad areas in which facts may be obtained and generalizations made. There is a great need for quantitation of salivary organisms, in order to gain precise information about their relative proportions. This knowledge may be of importance in the understanding of cariogenesis as well as in establishing the microbial aetiology of certain cases of periodontal disease in which this is so frequently obscure.

The purpose of the present paper, therefore, is to report counts of aerobic organisms per millilitre of saliva from apparently healthy children, with particular reference to the presence of organisms of established pathogenicity.

\section{Materials and Methods}

Fifty children aged between 7 and 12 years who were attending schools in the Muirhouse-Pilton area of Edinburgh were studied during February and March 1968. Most belonged to social classes III, IV, or V and the sex distribution was reasonably even. None had knowledg $\epsilon$ of a recent sore throat, mouth or lip infection, and none had any recent visits to the doctor. Nine had no caries; 26 had caries in one or two teeth and 15 had caries in three to five teeth.

Salivary specimens were taken by the author in the middle of the afternoon at least two hours after lunch had been taken. A sterile Pasteur pipette was used. This was calibrated to deliver drops of $0.02 \mathrm{ml}$ and was contained in a sterile test tube with 
a metal cap; a cotton wool plug at the foot prevented damage to the pipette. Plasticine was available to block the foot of the pipette and prevent saliva running out. This was not often necessary, however, if the tubes were kept on their sides. Occasionally it was difficult to obtain even a small amount of saliva from the children. No sialogogues were used in order to obtain a specimen but frequently, on the promise of a sweet, saliva was obtained from recalcitrant children. The pipette was placed on the floor of the anterior mouth, below the tongue, and the saliva was drawn up by the use of a rubber teat. One specimen only was obtained from each of the $\mathbf{5 0}$ children.

Assessment of the numbers of organisms in the saliva was made by the surface viable count method of Miles and Misra (1938). The specimen of saliva was diluted 1 in 4 with distilled water, and tenfold serial dilutions were made in distilled water from this suspension. Each suspension was mixed vigorously and Gram films of representative dilutions were prepared. Few aggregations of bacteria were seen. Bacterial counts on the same specimen showed little scatter, and clumping of bacteria in the present series did not have significant influence on the findings. Seven media were used: nutrient agar, horse blood agar, crystal violet blood agar, chocolate (ie, heated blood) agar, tomato juice agar, MacConkey's and Sabouraud's agar media (Cruickshank, 1965). Incubation was for 24 hours but for the isolation of lactobacilli and Candida species the appropriate plates were incubated for at least 48 hours. All organisms were identified by the appropriate tests (Cruickshank, 1965).

In this investigation the aerobic flora was studied. Anaerobic procedures were not employed and parallel incubation of plates in the presence of $\mathrm{CO}_{2}$ was not attempted. It was appreciated that yields of lactobacillus-like organisms would therefore be minimal.

\section{Results}

The following 15 groups of organisms were isolated from the salivary specimens: alpha-haemolytic 으 streptococci, beta-haemolytic streptococci, Strept. faecalis, pneumococci, Staphylococcus aureus, $\stackrel{D}{+}$ Staphylococcus albus, Staphylococcus citreus, Neisseria spp., including Neisseria meningitidis, 을 corynebacteria, lactobacilli, aerobic spore-bearing organisms of the Bacillus subtilis group, Haemophilus $\triangle$ influenzae, coliform organisms, and Candida spp. \& The percentage isolation rate of these organisms from the $\mathbf{5 0}$ salivary specimens is shown in Table $\mathrm{I}$.

\begin{tabular}{lc}
\hline Organism & Percentage Isolation \\
\hline Alpha-haemolytic streptococci & 98 \\
Beta-haemolytic streptococci & 22 \\
Strept. faecalis & 42 \\
Pneumococci & 76 \\
Staph. aureus & 2 \\
Staph. albus & 56 \\
Staph. citreus & 8 \\
Neisseria spp. & 84 \\
N. meningitidis & 4 \\
Corynebacteria & 78 \\
Aerobic lactobacilli & 48 \\
Aerobic spore-bearing organisms & 6 \\
Coliform organisms & 16 \\
H. influenzae & 24 \\
Candida spp. & 16 \\
\hline
\end{tabular}

Table I Percentage isolation rates of aerobic organisms from saliva of 50 schoolchildren

Alpha-haemolytic streptococci were most frequently isolated from the saliva and Staph. aureus most infrequently. The most commonly isolated organisms after alpha-haemolytic streptococci were neisseriae, corynebacteria, and pneumococci, and all of these groups were cultured from over $75 \%$ of salivary specimens.

Table II gives the analysis of the mean counts per $\mathrm{ml}$ of the organisms isolated from the saliva. Great differences can be seen in these. Alpha-haemolytic streptococci gave the highest counts per $\mathrm{ml} \mathrm{(1.6 \times}$ $\left.10^{7}-1.7 \times 10^{7}\right)$ and the lowest, less than $1 \times 10^{5}$, were produced by Staph. aureus, coliform organisms, and Candida spp. Seven of the 15 groups of organisms gave mean counts of between $1 \times 10^{5}$ and $5 \times 10^{5}$ per ml. Mean counts of the known pathogens

\begin{tabular}{|c|c|c|c|c|c|c|}
\hline \multirow{2}{*}{$\frac{\text { Organisms Isolated }}{<1 \times 10^{5}}$} & \multirow{2}{*}{\multicolumn{2}{|c|}{$\frac{d \text { within the Range }<1 \times 10^{5}-1.7 \times 10}{1 \times 10^{5}-5 \times 10^{5}} \frac{1 \times 10^{5}-1 \times 10^{5}}{5 \times 1}$}} & \multirow{2}{*}{$\frac{0^{7} \text { per } m l}{2 \times 10^{4}-3 \times 10^{6}}$} & \multirow[b]{2}{*}{$5 \times 10^{6}-6 \times 10^{0}$} & \multirow{2}{*}{\multicolumn{2}{|c|}{$9 \times 10^{4}-10 \times 10^{6} 1.6 \times 10^{7}-1.7 \times 10^{7}$}} \\
\hline & & & & & & \\
\hline $\begin{array}{l}\text { Staph. aureus } \\
\text { Coliforms } \\
\text { Candida spp. }\end{array}$ & $\begin{array}{l}\text { Staph. citreus } \\
\text { Strept. faecalis } \\
\text { Aerobic spore- } \\
\text { bearers } \\
\text { Lactobacilli } \\
N . \text { meningitidis } \\
H . \text { influenzae } \\
\text { Beta-haemolytic } \\
\text { streptozocci }\end{array}$ & Staph. albus & Corynebacteria & Neisseria spp. & Pneumococci & $\begin{array}{l}\text { Alpha- } \\
\text { haemolytic } \\
\text { streptococci }\end{array}$ \\
\hline
\end{tabular}

Table II Aerobic organisms isolated from saliva of 50 schoolchildren'

${ }^{1}$ Mean viable counts per $\mathrm{ml}$ 
exceeded $1 \times 10^{5}$ per $\mathrm{ml}$ except in the case of Staph. aureus.

\section{Discussion}

By culturing 15 different organisms from the salivary specimens it was considered that most, if not all, of the groups of aerobic organisms had been isolated. Many more organisms exist, however, in the anaerobic flora.

Alpha-haemolytic streptococci were the organisms most frequently isolated; their mean count was higher than that reported either by Kraus and Gaston (1956) or by Richardson and Jones (1958). No satisfactory explanation can be offered for failing to isolate them from one of the specimens. The child had not received any antibiotics nor was there any technical error in processing the specimen. Betahaemolytic streptococci were cultured from $22 \%$ of specimens, mostly from children who were throat carriers of haemolytic streptococci; as long as the children remained throat carriers these organisms could be isolated from the saliva. The mean count was in the region of $2 \times 10^{5}$ per ml. This was considerably lower than $1.4 \times 10^{6}$ per ml demonstrated as the mean count in samples of saliva from children with acute streptococcal sore throat by Ross (1970). Strept. faecalis organisms were contained in a greater proportion of mouths than the $21.8 \%$ reported by Williams, Forbes, Blau, and Eickenberg (1950).

A notable finding was the frequent isolation of large numbers of pneumococci. Burnett and Scherp (1962) described these organisms as transient and Lucas and Kramer (1966) stated that they were very rarely found in the mouth. Clearly, however, they are prominent oral organisms. A similar situation obtained with staphylococci.

Non-pathogenic neisseriae were isolated with great frequency and in large numbers. Again there is disagreement with the statement of Burnett and Scherp (1962) that they are transient organisms. $N$. meningitidis was cultured from two salivary samples, but the counts were low. They may well have been commensal mouth organisms although Lucas and Kramer deny that pathogenic neisseriae can fill this role. Corynebacteria ('diphtheroids') were also commonly found and lactobacilli were isolated from approximately half the salivary specimens; Lucas and Kramer (1966) stated that lactobacilli were always present in the mouth, albeit in numbers that varied considerably, but this was not found to be so in the present study. As the association of these organisms with dental caries is widely accepted, isolation rates and mean counts per ml were compared from mouths with no caries, slight caries, and more severe caries. No statistically significant inter-group differences were found. Burnett and Scherp stated that $H$. influenzae is a transient organism in the mouth; in the present series approximately $25 \%$ of the salivary specimens contained these organisms. Counts of coliform organisms and Candida species were low and their isolation rate was $16 \%$ in each case. Richardson and Jones (1958) also reported low counts for these organisms.

In the present series the approximate numbers of organisms that constitute the aerobic salivary flora have been calculated, and in addition the isolation rate and counts of known pathogens are reported. Staph. aureus, beta-haemolytic streptococci, pneumococci, $N$. meningitidis, and $\mathrm{H}$. influenzae were isolated from salivary specimens from 50 children and all except Staph. aureus produced mean counts of over $1 \times 10^{5}$ per ml. These figures underline the importance of the saliva as a source of crossinfection because it is known that the risk of crossinfection is increased when the saliva is heavily infected, and the present results show that this can often be the case.

It is felt that there is a great need to quantitate salivary organisms and oral organisms in general in healthy and diseased mouths, in order to study infective conditions more precisely. Studies have been conducted on the aerobic flora in this paper, but there is room for extended studies on the composition and numbers of the anaerobic flora in order to gain more information on the ecology of organisms of the mouth and the pathogenesis of oral infections.

\section{References}

Burnett, G. W. and Scherp, H. W. (1962) Oral Microbiology and Infectious Diseases. Williams and Wilkins, Baltimore.

Cruickshank, R., ed. (1965). Medical Microbiology, 11th ed. Livingstone, Edinburgh.

Hoffman, H. (1966). Oral microbiology. Advanc. appl. Microbiol., 8, 195-251.

Johnston, D. A., and Bodey, G. P. (1970). Semi-quantitative oropharyngeal culture technique. Appl. Microbiol., 20, 218-223.

Kraus, F. W. (1958). Microbiology of the oral cavity and its systemic significance. Dent. Clin. N. Amer., July, 309.324.

Kraus, F. W., and Gaston, C. (1956). Individual constancy of numbers among the oral flora. J. Bact., 71, 703-707.

Miles, A. A., and Misra, S. S. (1938). The estimation of the bactericidal power of the blood. J. Hyg., 38, 732-749.

Lucas, R. B., and Kramer, I. R. H. (1966). Bacteriology for Students of Dental Surgery. Churchill, London.

Morris, E. O. (1953a). The bacteriology of the oral cavity. I. The distribution of the bacteria in and on the dental enamel. Brit. dent. J., 95, 77-82.

Morris, E. O. (1953b). The bacteriology of the oral cavity. IIa. Methods used in the study of the oral cavity. Brit. dent. J., 95, 259-270.

Morris, E. O. (1954a). The bacteriology of the oral cavity. III. Streptococcus. Brit. dent. J., 96, 95-108.

Morris, E. O. (1954b). The bacteriology of the oral cavity. IVa. Micrococcus neisseria (b) and veillonella (c). Brit. dent. J., 96, 259-265.

Morris, E. O. (1954c). The bacteriology of the oral cavity. V. 
Corynebacterium and Gram-positive filamentous organisms. Brit. dent. J., 97, 29-36.

Morris, E. O. (1954d). The bacteriology of the oral cavity. VI, Fusiformis, bacillus, bacterium and haemophilus. General conclusions. Brit. dent. J., 97, 284-291.

Richardson, R. L., and Jones, M. (1958). A bacteriologic census of human saliva. J. dent. Res., 37, 697-709.

Ross, P. W. (1970). MD Thesis, University of Aberdeen.

Williams, N. B., Forbes, M. A., Blau, E, and Eickenberg, C. F. (1950). A study of the simultaneous occurrence of enterococci, lactobacilli, and yeasts in saliva from human beings. J. dent. Res., 29, 563-570.

\section{Reports and Bulletins prepared by the Association of Clinical Biochemists}

The following reports and bulletins are published by the Association of Clinical Biochemists. They may be obtained from The Administrative Office, Association of Clinical Biochemists, 7 Warwick Court, Holborn, London, WC1R 5DP. The prices include postage, but airmail will be charged extra. Overseas readers should remit by British Postal or Money Order. If this is not possible the equivalent of $50 \mathrm{p}$ is the minimum amount that can be accepted.

SCIENTIFIC REPORTS

3 Automatic Dispensing Pipettes. An assessment of 35 commercial instruments 1967 P. M. G. BROUGHTON, A. H. GOWENLOCK, G. M. WIDDOWSON, and K. A. AHLQUIST $85 p(\$ 2)$

4 An Evaluation of five Commercial Flame Photometers suitable for the Simultaneous Determination of Sodium and Potassium March 1970 P. M. G. BROUGHTON and J. B. DAWSON $85 p(\$ 2)$

\section{SCIENTIFIC REVIEWS}

1 The Assessment of Thyroid Function March 1971 F. V. FLYNN and J. R. HOBBS $62 \frac{1}{2} p(\$ 1.50)$

TECHNICAL BULLETINS

9 Determination of Urea by AutoAnalyzer November

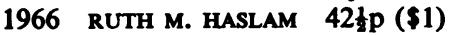

11 Determination of Serum Albumin by AutoAnalyzer using Bromocresol Green October 1967 B. E. NORTHAM and G. M. WIDDOWSON $42 \frac{1}{2}$ (\$1)

13 An Assessment of the Technicon Type II Sampler Unit March 1968 B. C. GRAY AND G. K. MCGOWAN 42⿺ p (\$1)

14 Atomic Absorption Spectroscopy. An outline of its principles and a guide to the selection of instruments May 1968 J. B. DAWSON and P. M. G. BROUGHTON $42 \frac{1}{2} p(\$ 1)$
15 A Guide to Automatic Pipettes (2nd edition) June 1968 P. M. G. BROUGHTON $42 \frac{1}{2} \mathrm{p}(\$ 1)$

16 A Guide to Automation in Clinical Chemistry May 1969 P. M. G. BROUGHTON 62站 $(\$ 1.50)$

17 Flame Photometers (2nd edition) 1969 P. WILdING $62 \frac{1}{2} \mathrm{p}(\$ 1.50)$

18 Control Solutions for Clinical Biochemistry (4th edition) March 1970 P. M. G. BROUGHTON 621 p (\$1.50)

19 Spectrophotometers. A comparative list of low-priced instruments readily available in Britain May 1970 C. E. WILDE and P. SEWELL $62 \frac{1}{2} \mathrm{p}(\$ 1.50)$

20 Quantities and Units in Clinical Biochemistry June 1970 P. M. G. BROUGHTON 62tp (\$1.50) More than 30 copies in units of 10 at $20 p$

21 Filter Fluorimeters: A comparative list of 18 instruments September 1970 H. BRAUNSBERG and s. S. BROWN $62 \mathrm{tp}(\$ 1.50)$

22 Bilirubin standardsand the Determination of Bilirubin by Manual and Technicon AutoAnalyzer Methods. \& January 1971 BARBARA BILLING, RUTH HASLAM and N. WALD $62 \frac{1}{2} \mathrm{p}(\$ 1.50)$

23 Interchangeable Cells for Spectrophotometers and Fluorimeters September 1971 E. S. BROWN and A. H. GOWENLOCK $62 \frac{1}{2} p(\$ 1.50)$ 